\title{
Analysis of the Influence of Local Government's Behavior and Preference on Industrial Agglomeration Under Chinese Promotion Game
}

\section{Chuan Yan}

School of Public Finance and Taxation, Central University of Finance and Economics, Beijing, China

\author{
Email address:
}

yansifei2010@126.com

\section{To cite this article:}

Chuan Yan. Analysis of the Influence of Local Government's Behavior and Preference on Industrial Agglomeration Under Chinese Promotion Game. International Journal of Economics, Finance and Management Sciences. Vol. 6, No. 2, 2018, pp. 43-53.

doi: $10.11648 /$ j.ijefm.20180602.12

Received: March 7, 2018; Accepted: March 21, 2018; Published: April 13, 2018

\begin{abstract}
Research content: Based on the framework of Chinese-style promotion game, a theoretical model to describe how local government behavior and preference affect agglomeration is made up, and empirical evidence is provided based on the samples from 282 cities in China. Innovation: Taking industrial connections as the grasp of the hand, different effects of local government behavior and preference on the agglomeration of manufacturing industry and production service industry are identified, which provides a new perspective for the explanation of the causes of agglomeration economy in China. Main conclusions: (1) In the Chinese promotion game, local government officials will promote local manufacturing industry agglomeration and producer services industry agglomeration for the maximization of their promotion profits, but prefer to promote manufacturing industry agglomeration. (2) The connection between producer services industry and manufacturing industry, and the connection within manufacturing industries will affect local governments' industry selection preference, the former can induce local governments to tend to pull up the agglomeration of producer services industry, the latter can induce local governments to tend to pull up the manufacturing industry agglomeration.
\end{abstract}

Keywords: Promotion Game, Fiscal Decentralization, Agglomeration, Productive Service Industry, Industrial Association

\section{Introduction}

Industrial agglomeration has been one of the hot spots of academic research in recent years. As an important economic phenomenon, the academia has been trying to explain its possible driving forces. Theories of agglomeration interpretation keep evolving from "Traditional economic geography" (Ohlin, 1933 [1]; Christaller, 1966 [2]; Henderson, 1991[3]) to "New economic geography" (Krugman, 1991) [4], along with research paradigm gradually evolving from the neoclassical economics paradigm to the general dynamic equilibrium paradigm. After twenty-first century, with the thought of institutional economics entering into the researches of industrial agglomeration, how government and its policies affect industrial agglomeration is getting more and more attention. Tax competition theory suggests that, the tax reduction policy of the regional government will have an attractive effect on enterprises, which leads to regional industrial agglomeration. Meanwhile, industrial agglomeration will lead to the continuous "downward competition" of the actual tax rates among different regions in turn, until "Race to the bottom" (Wilson, 1999) [5]. Brakman(2002) [6] brings the provision of public goods into the analytical framework of new economic geography and suggests that the provision of public goods is able to induce industrial agglomeration and break the spatial equilibrium of industrial distribution. Bucovetsky (2005) [7] builds up a game theory model of government expenditure competition and theoretically analyzes the inducing effect of regional government expenditure competition on industrial agglomeration. Egger and Falkinger(2006) [8] provide a proof in a competition model of two country that public infrastructure investment will attract the agglomeration of intermediate input production enterprises. Commendatore et al. (2008) [9] explains the mechanism of the pulling effect of government expenditure on industrial agglomeration by 
modify the "C-P" model of new economic geography. Fenge et al. (2009) [10] introduce government public investment competition into the framework of new economic geography and find out that when the transaction cost is high, the government's public investment competition will lead to the dispersed distribution of industry, and when the transaction cost is reduced to a certain extent, the government's public investment competition will induce industrial agglomeration. Tsai (2017) [11] investigates the influence of the spillover effect of the regional government's public goods on the regional industrial agglomeration and find out that the spillover effect of public goods has a diffusion effect on industrial agglomeration: when the cost of transportation is low enough, regions that enjoy more spillover effects from other areas of public goods will attract more mobile labor, which will induce higher industrial agglomeration level.

The theoretical and empirical studies on how government and its policies affect regional industrial agglomeration in China also mainly lie in the framework of new economic geography. Jin et al. (2006) [12] carry out an empirical test using the provincial panel data of China from 1987 to 2001 and finds out a reverse relationship between government expenditure and regional industrial agglomeration, which means that the weaker the government's role is, the more conducive to the industrial agglomeration of the region. Huang and $\mathrm{Li}$ (2006) [13] uses the proportion of fiscal revenue to GDP to measure the degree of local government protection of industrial industry on the level of provinces in China and find out a positive correlation between local government protection and regional industrial agglomeration. Liang and $\mathrm{Wu}(2008)$ [14] theoretically explore the influence mechanism of Chinese financial transfer payment system on industrial agglomeration and point out that the financial transfer payment in China will lead to the trend of the industry centralization to the superior administrative region. Chen et al. (2009) [15] find that the scale of government expenditure has a significant negative impact on the agglomeration of productive service industry based on the cross section data of 222 cities in China in 2007. He et al. (2010) [16] use the data of China's first economic census in 2004 and point out the positive impact of provincial government expenditure on industrial agglomeration on the provincial level. Hu et al. (2011) [17] demonstrate the theoretically influencial mechanism of government intervention on industrial agglomeration from four dimensions of policy means such as development strategy, industry and trade policy, market regulation, public investment construction, and point out that government is the "external motive force" of industrial agglomeration. Zong and Zhu (2013) [18] make a empirical analysis using provincial panel data of China based on the theoretical framework of Commendatore et al. (2008) [9], and find out that productive public expenditure has a positive impact on industrial agglomeration on the provincial level in China. Li et al. (2017) [19] uses provincial panel data of China and analyze empirically whether the differences of local government policy and behavior will affect the regional industrial agglomeration, and find out that industrial policy, public service policy and open-up policy have a positive impact on industrial agglomeration, while fiscal policy has a significant negative impact.

From the above literature, we can see that once the research object is determined to be China, different theories and empirical studies on the influence of government and policy on the evolution of industrial agglomeration have resulted in contradictory conclusion, the explanatory power of the mainstream new economic geography theory weakens and is unable to provide a perfect explanation for the anormaly existing in China. Li et al. (2014) [20] make a systematic literature review and suggest that the reason for this phenomenon is that the existing research has taken government behavior and policy as the "accidental" factor and "exogenous" factor in the industrial agglomeration, and neglecting the endogenous influence of government behavior and policies on the evolution of industrial agglomeration, which is not in accordance with the actual situation in China. In China, governments (especially the local governments) have a huge impact on all aspects of economic and social development. Local governments at all levels act as the institutional environment provider in the development of local industry, and their behavior and preference have a significant impact on the development of local industry. In view of this, this paper tries to provide an interpretation framework for industrial agglomeration from the perspective of local government behavior and preference, in order to enrich the existing theoretical system of industrial agglomeration interpretation and provide a new perspective for the explanation of the causes of industrial agglomeration in China.

\section{Theoretical Model}

As the largest developing country in the world, China's national and government policies have a particularly significant impact on the economic development (Lin, 2008) [21]. The special "political centralization + economic decentralization" has led to the "political Championships" between local governments, which has a significant role in shaping the behavior and preference of local government officials in China (Zhou, 2004 [22]; Zhou, 2007 [23]). This section uses Yu and Liu (2018) [24]'s idea of model building for reference, and construct an industrial agglomeration evolution model based on the framework of promotion game between local governmental officials, in order to make an attempt to describe the role of local government's behavior and preference in the process of industrial agglomeration. In order to distinguish the nature of different types of industry, in this section, the manufacturing industry in the industrial industry and the productive service industry in the service industry are respectively examined.

The economic performance of each place is set to be $y_{i}$; The local "available" economic resources in the broad sense is set to be $S_{i}$, which includes available land, urban space, environmental carrying capacity, etc. We assume the amount of local "available" economic resources is able to be changed by local governments. For example, local governments can 
build new economic development zones, selling more industrial land and commercial land, building more urban infrastructure, and so on. It is obvious that the more local economic resources is being exploited, the greater the promotion effect on the local economy is. The effort of local government official is set to be $a_{i}$. Local economic performance can be expressed as:

$$
y_{i}=S_{i} a_{i}+r S_{j} a_{j}+e_{i}
$$

Among them, the coefficient $r$ represents the spatial spillover effect of the official's effort in region $\mathrm{j}$ on the economic performance of regional $\mathrm{i}$, which is set to be $|r|<1$ according to Zhou (2004) [22]. $e_{i}$ is stochastic disturbance term, $e_{i}$ and $e_{j}$ are mutually independent and obey a symmetric distribution of $\mathrm{F}$, which is expected to be zero mean, independent and identical. According to the rules of the "political Championships", if $y_{i}>y_{j}$, then official in i region will be promoted, which gives this official a direct utility of $\mathrm{V}$. Meanwhile, official in $\mathrm{j}$ region fails to be promoted. Because of beating the competitors, official in i region also get an indirect utility of $\mathrm{v}(\mathrm{V}>\mathrm{v})$. The probability of promotion of the official in i region can be expressed as:

$$
\begin{gathered}
\operatorname{Pr}\left(y_{i}>y_{j}\right)=\operatorname{Pr}\left(S_{i} a_{i}+r S_{j} a_{j}+e_{i}-S_{j} a_{j}-r S_{i} a_{i}-e_{j}>0\right)=\operatorname{Pr}\left[e_{j}-e_{i}<(1-r)\left(S_{i} a_{i}-S_{j} a_{j}\right)\right] \\
=F\left[(1-r)\left(S_{i} a_{i}-S_{j} a_{j}\right)\right]
\end{gathered}
$$

The effort cost of local offcial is set to be $C\left(a_{i}\right), C\left(a_{i}\right)^{\prime}>0$ and $C\left(a_{i}\right)^{\prime \prime}>0$ (Zhou, 2004) [22]. Therefore, the utility function of offcial in i region can be expressed as:

$$
U_{i}\left(a_{i}, a_{j}\right)=F\left[(1-r)\left(S_{i} a_{i}-S_{j} a_{j}\right)\right] V+\left\{1-F\left[(1-r)\left(S_{i} a_{i}-S_{j} a_{j}\right)\right]\right\} v-C\left(a_{i}\right)
$$

The first order condition for the official in $\mathrm{i}$ region maximazing his utility is:

$$
S_{i}=\frac{C\left(a_{i}\right)^{\prime}}{f(\cdot)(1-r)(V-v)}\left(f(\cdot)=F(\cdot)^{\prime}\right)
$$

According to (2), the higher the efforts of local government officials, the more the officials tend to dig more "available" economic resources in his jurisdiction, which is quite in line with the reality in China. A similar conclusion can be obtained from the perspective of the maximization of social general welfare (Yu and Liu, 2018) [24].

While local officials are making full use of local "available" economic resources, in order to develop local economy, they will formulate industrial policies, attract investment and attract industrial agglomeration to form an agglomeration economy, because the effect of agglomeration on the local economy has been quite obvious to all. In the next two cases, the preference of local government's industry selection is analyzed respectively.

\subsection{Non-Increasing Return of Scale}

Suppose local government officials are rational, and will try their best to pull the local economic performance in exchange for the promotion opportunity. Suppose the initial manufacturing industry level of a place is $x_{0}$, the initial productive service industry level of a place is $y_{0}$. Suppose the economic performance brought about by agglomeration is Cobb-Douglas form: $\pi=A\left(x+x_{0}\right)^{a}\left(y+y_{0}\right)^{b}(0<a<$ $1,0<b<1, a+b \leq 1)$. $\mathrm{x}$ is the change in the level of manufacturing industry agglomeration, $y$ is the change in the level of productive service industry agglomeration, and obviously $x+x_{0}>0$ and $y+y_{0}>0$. Because the agglomeration of manufacturing industry and the agglomeration of productive service industry are interdependent (They are linked by industrial connections), meanwhile as the level of agglomeration increases, the cost of congestion is increasing, therefore setting the agglomeration economy performance to be Cobb Douglas form which is of non-increasing returns of scale has certain rationality. Because the industrial nature of productive service industry, whose labor productivity rate is lower relative to the manufacturing industry, which means lower pulling effect on local economy performance than manufacturing industry (Chen et al., 2009) [15], therefore we can suppose $a>b$. Suppose A to be the technical efficiency of agglomeration.

Because the "available" economic resources $S_{i}$ in place i are limited, therefore, there is an upper limit constraint on the agglomeration level. When a local official takes his office, in order to maximize local economic performance, the official is supposed to have a motive to optimize the following questions:

$$
\left\{\begin{array}{c}
\text { minimize: }-A\left(x+x_{0}\right)^{a}\left(y+y_{0}\right)^{b} \\
\text { s.t: } x+x_{0}+y+y_{0} \leq S_{i}
\end{array}\right.
$$

Because when $0<a<1,0<b<1, a+b \leq 1, A(x+$ $\left.x_{0}\right)^{a}\left(y+y_{0}\right)^{b}$ is a concave function in $R_{2}^{+}$, therefore the objective function in the optimization question of (3) is convex. Meanwhile, because the constraint condition in (3) is linear, therefore Kuhn-Tucker condition (KKT) is able to be applied, which means that the optimum solution of (3) $\left(x^{*}, y^{*}\right)$ satisfy the following conditions:

$$
\left\{\begin{array}{c}
x^{*}+y^{*}+x_{0}+y_{0} \leq S_{i} \\
\lambda^{*} \geq 0 \\
\lambda^{*}\left(x^{*}+y^{*}+x_{0}+y_{0}-S_{i}\right)=0 \\
-a A\left(x^{*}+x_{0}\right)^{a-1}\left(y^{*}+y_{0}\right)^{b}+\lambda^{*}=0 \\
-b A\left(x^{*}+x_{0}\right)^{a}\left(y^{*}+y_{0}\right)^{b-1}+\lambda^{*}=0
\end{array}\right.
$$

Because $x+x_{0}>0$ and $y+y_{0}>0$, therefore $\lambda^{*}>0$, which leads to:

$$
x^{*}+y^{*}+x_{0}+y_{0}-S_{i}=0
$$

That is, local officials will make full use of all the available economic resources that have been developed in his jurisdiction to invest in the local economic development. Meanwhile, it can be seen from (5) that: $a A\left(x^{*}+\right.$ 
$\left.x_{0}\right)^{a-1}\left(y^{*}+y_{0}\right)^{b}=\lambda^{*}=b A\left(x^{*}+x_{0}\right)^{a}\left(y^{*}+y_{0}\right)^{b-1}$ which leads to:

$$
a\left(y^{*}+y_{0}\right)=b\left(x^{*}+x_{0}\right)
$$

From (5) and (6), we have:

$$
\left\{\begin{array}{l}
x^{*}=\frac{a}{a+b} S_{i}-x_{0} \\
y^{*}=\frac{b}{a+b} S_{i}-y_{0}
\end{array}\right.
$$

Substituting (2) into (7), The expression of the best industrial agglomeration ratio in the eyes of local government official is:

$$
\left\{\begin{array}{l}
x^{*}+x_{0}=\frac{a}{a+b} \times \frac{c\left(a_{i}\right)^{\prime}}{f(\cdot)(1-r)(V-v)} \\
y^{*}+y_{0}=\frac{b}{a+b} \times \frac{c\left(a_{i}\right)^{\prime}}{f(\cdot)(1-r)(V-v)}
\end{array}\right.
$$

$$
\pi=\mathrm{f}\left(\mathrm{x}+x_{0}, \mathrm{y}+y_{0}\right)=a\left(x+x_{0}\right)^{2}+b\left(y+y_{0}\right)^{2}+2 c\left(x+x_{0}\right)\left(y+y_{0}\right),(a>0, \mathrm{~b}>0, \mathrm{c}>0)
$$

Because when $n>1$ :

$$
\begin{aligned}
\mathrm{f}\left(\mathrm{n}\left(\mathrm{x}+x_{0}\right), \mathrm{n}\left(\mathrm{y}+y_{0}\right)\right)=n^{2}\left[a\left(x+x_{0}\right)^{2}+b\left(y+y_{0}\right)^{2}+2 c\left(x+x_{0}\right)\left(y+y_{0}\right)\right] \\
>\operatorname{nf}\left(\mathrm{x}+x_{0}, \mathrm{y}+y_{0}\right)
\end{aligned}
$$

Therefore this objective function satisfies the condition of increasing returns to scale. The $2 c\left(x+x_{0}\right)\left(y+y_{0}\right)$ can be seen as the connection between manufacturing industry and productive service industry. Suppose $a>b>2 c>0$, which means the pulling effect of manufacturing industry on local economic performance is greater than that of productive service industry, and the individual pulling effect of the two is greater than the connection effect.

Now, the problem of local officials' optimization is changed into:

$$
\left\{\begin{array}{c}
\text { minimize: }-a\left(x+x_{0}\right)^{2}-b\left(y+y_{0}\right)^{2}-2 c\left(x+x_{0}\right)\left(y+y_{0}\right) \\
x+x_{0}+y+y_{0} \leq S_{i}
\end{array}\right.
$$

For the optimization question like (9), because of the apparent existence of $(\mathrm{x}, \mathrm{y})$, which satisfies $x+x_{0}+y+$ $y_{0}<S_{i}$, therefore Slater constraint is satisfied, which means (9) and its dual problems satisfy strong duality [25]. Because both the objective function and the constraint function are differentiable in (9), therefore the optimum solution of $\left(x^{*}, y^{*}\right)$ for (9) satisfies Kuhn-Tucker condition (KKT):

$$
\left\{\begin{array}{c}
x^{*}+y^{*}+x_{0}+y_{0} \leq S_{i} \\
\lambda^{*} \geq 0 \\
\lambda^{*}\left(x^{*}+y^{*}+x_{0}+y_{0}-S_{i}\right)=0 \\
-2 a\left(x^{*}+x_{0}\right)-2 c\left(y^{*}+y_{0}\right)+\lambda^{*}=0 \\
-2 b\left(y^{*}+y_{0}\right)-2 c\left(x^{*}+x_{0}\right)+\lambda^{*}=0
\end{array}\right.
$$

From (10), because $x+x_{0}>0$ and $y+y_{0}>0$, therefore $\lambda^{*}>0$, which leads to

$$
x^{*}+y^{*}+x_{0}+y_{0}-S_{i}=0
$$

From (10), we can also get:

$$
(a-c)\left(x^{*}+x_{0}\right)=(\mathrm{b}-\mathrm{c})\left(y^{*}+y_{0}\right)
$$

From (11) and (12), we have:

$$
\left\{\begin{array}{l}
x^{*}=\frac{b-c}{a+b-2 c} S_{i}-x_{0} \\
y^{*}=\frac{a-c}{a+b-2 c} S_{i}-y_{0}
\end{array}\right.
$$

If we mark $a^{*}=a-c, b^{*}=b-c$ (now $a^{*}>b^{*}>0$ ), we can see that (7) and (13) has the exactly same form. Also, substitute (2) into (13), conclusions like (8) can also be drawn. The following analysis is based on (8) results.

\subsection{Propositions}

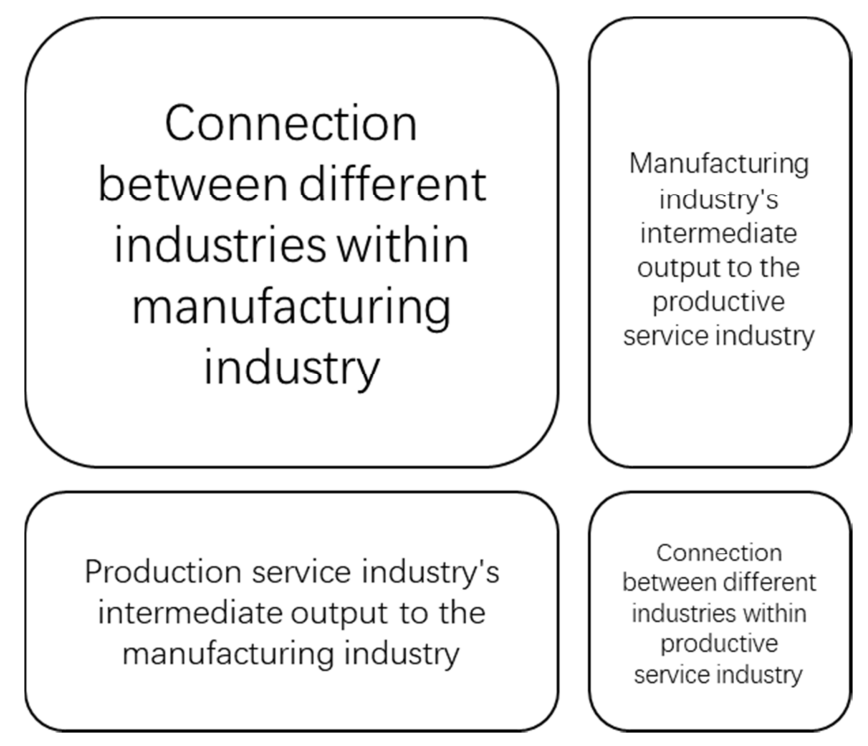

Figure 1. Structure of Input-Output Table. 
Because it is difficult to quantify $a$ and $b$ in (8), therefore it is difficult to identify them when searching for empirical evidence. However, it is easy to notice that, for the productive service industry, because its development mainly depends on embdding into the value chain of the manufacturing industry by undertaking the outsourcing work of manufacturing intermediate products, so the connection between producer services industry and manufacturing industry will directly affect the pulling effect of producer services industry on the local economy. To put it simply, if the producer service industry in one place cannot satisfy the needs of manufacturing enterprises very well, no matter how many producer services enterprise there is, the pulling effect on the local economy will not be strong enough. Therefore, according to the input-output table structure (Figure 1), we can suppose the pulling effect of productive service industry agglomeration on local economy satisfies:

$$
\mathrm{b}=g(\text { con_sm }), g(\text { con_sm })^{\prime}>0
$$

In (14), con_sm is the connection between local manufacturing industry and local productive service industry, we can measure it by calculating the total input and output amount of area $\beta$ and $\gamma$ in figure 1, which includes two parts, one is production service industry's service output to the manufacturing industry, the other is production services industry's procurement for manufacturing products. Similarly, the pulling effect of manufacturing industry on local economy can be set to be:

$$
a=h(\text { con_mm }), h\left(c o n \_m m\right)^{\prime}>0
$$

In (15), con_mm is the connection between the various industries within the manufacturing industry, we can measure it by calculating the total input and output amount of area $\alpha$ in figure 1, which is the total input and output of each industry within the manufacturing industry. (15) means that the pulling effect of manufacturing industry on local economy is positively affected by the connection among different industries within the manufacturing industry, which is also quite consistent with the law of economic development: The cooperative development of various industries will always be more vibrant than the isolated development of various industries.

Substituting (14) and (15) into (8), we have:

$$
\left\{\begin{array}{l}
x^{*}+x_{0}=\frac{h\left(c o n \_m m\right)}{h\left(c o n \_m m\right)+g\left(c o n \_s m\right)} \times \frac{C\left(a_{i}\right)^{\prime}}{f(\cdot)(1-r)(V-v)} \\
y^{*}+y_{0}=\frac{g\left(c o n \_s m\right)}{h\left(c o n \_m m\right)+g\left(c o n \_s m\right)} \times \frac{C\left(a_{i}\right)^{\prime}}{f(\cdot)(1-r)(V-v)}
\end{array}\right.
$$

From (16), we can have partial derivatives below:

$$
\begin{aligned}
& \left\{\begin{aligned}
\frac{\partial\left(x^{*}+x_{0}\right)}{\partial a_{i}} & =\frac{h\left(c o n \_m m\right)}{h\left(c o n \_m m\right)+g\left(c o n \_s m\right)} \cdot \frac{C\left(a_{i}\right)^{\prime \prime}}{f(\cdot)(1-r)(V-v)}>0 \\
\frac{\partial\left(x^{*}+x_{0}\right)}{\partial c o n \_m m} & =\frac{h\left(c o n \_m m\right)^{\prime} g\left(c o n \_s m\right)}{\left[h\left(c o n \_m m\right)+g\left(c o n \_s m\right)\right]^{2}} \cdot \frac{C\left(a_{i}\right)^{\prime}}{f(\cdot)(1-r)(V-v)}>0 \\
\frac{\partial\left(x^{*}+x_{0}\right)^{2}}{\partial a_{i} \partial c o n \_m m} & =\frac{C\left(a_{i}\right)^{\prime \prime}}{f(\cdot)(1-r)(V-v)} \cdot \frac{h\left(c o n \_m m\right)^{\prime} g\left(c o n \_s m\right)}{\left[h\left(c o n \_m m\right)+g\left(c o n \_s m\right)\right]^{2}}>0 \\
\frac{\partial\left(x^{*}+x_{0}\right)}{\partial c o n \_s m} & =\frac{-g\left(c o n \_s m\right)^{\prime} h\left(c o n \_m m\right)}{\left[h\left(c o n \_m m\right)+g\left(c o n \_s m\right)\right]^{2}} \cdot \frac{C\left(a_{i}\right)^{\prime}}{f(\cdot)(1-r)(V-v)}<0 \\
\frac{\partial\left(x^{*}+x_{0}\right)^{2}}{\partial a_{i} \partial c o n \_s m} & =\frac{-g\left(c o n \_s m\right)^{\prime} h\left(c o n \_m m\right)}{\left[h\left(c o n \_m m\right)+g\left(c o n \_s m\right)\right]^{2}} \cdot \frac{C\left(a_{i}\right)^{\prime \prime}}{f(\cdot)(1-r)(V-v)}<0
\end{aligned}\right. \\
& \left\{\begin{array}{c}
\frac{\partial\left(y^{*}+y_{0}\right)}{\partial a_{i}}=\frac{g\left(c o n \_s m\right)}{h\left(c o n \_m m\right)+g\left(c o n \_s m\right)} \cdot \frac{C\left(a_{i}\right)^{\prime \prime}}{f(\cdot)(1-r)(V-v)}>0 \\
\frac{\partial\left(y^{*}+y_{0}\right)}{\partial c o n \_m m}=\frac{-h\left(c o n \_m m\right)^{\prime} g\left(c o n \_s m\right)}{\left[h\left(c o n \_m m\right)+g\left(c o n \_s m\right)\right]^{2}} \cdot \frac{C\left(a_{i}\right)^{\prime}}{f(\cdot)(1-r)(V-v)}<0 \\
\frac{\partial\left(y^{*}+y_{0}\right)^{2}}{\partial a_{i} \partial c o n \_m m}=\frac{-h\left(c o n \_m m\right)^{\prime} g\left(c o n \_s m\right)}{\left[h\left(c o n \_m m\right)+g\left(c o n \_s m\right)\right]^{2}} \cdot \frac{C\left(a_{i}\right)^{\prime \prime}}{f(\cdot)(1-r)(V-v)}<0 \\
\frac{\partial\left(y^{*}+y_{0}\right)}{\partial c o n \_s m}=\frac{g\left(c o n \_s m\right)^{\prime} h\left(c o n \_m m\right)}{\left[h\left(c o n \_m m\right)+g\left(c o n \_s m\right)\right]^{2}} \cdot \frac{C\left(a_{i}\right)^{\prime}}{f(\cdot)(1-r)(V-v)}>0 \\
\frac{\partial\left(y^{*}+y_{0}\right)^{2}}{\partial a_{i} \partial c o n \_s m}=\frac{g\left(c o n \_s m\right)^{\prime} h\left(c o n \_m m\right)}{\left[h\left(c o n \_m m\right)+g\left(c o n \_s m\right)\right]^{2}} \cdot \frac{C\left(a_{i}\right)^{\prime \prime}}{f(\cdot)(1-r)(V-v)}>0
\end{array}\right.
\end{aligned}
$$

From sub-results in (17) and (18), we have propositions below:

Proposition 1: In the Chinese promotion game, local government officials will promote the agglomeration of local manufacturing industry and the agglomeration of productive services in order to maximize the probability of their promotion.

Proposition 2: Due to the producer services industry' natural dependence on the manufacturing industry, the higher the connection between local producer services industry and manufacturing industry, the stronger the pulling effect of producer services industry on local economy, therefore local government officials will be more willing to pull up the level of local productive service industry agglomeration and reduce the level of manufacturing industry agglomeration relatively.

Proposition 3: The higher the connection among different industries within manufacturing industry, the stronger the pulling effect of manufacturing industry on local economy, therefore local government officials will be more willing to pull up the level of local manufacturing industry agglomeration and reduce the level of productive service industry agglomeration relatively.

On the other hand, if we do a difference between the two sub-results in (16), we have: 


$$
\left(x^{*}+x_{0}\right)-\left(y^{*}+y_{0}\right)=\frac{h\left(c o n \_m m\right)-g\left(c o n \_s m\right)}{h\left(c o n \_m m\right)+g\left(c o n \_s m\right)} \times \frac{C\left(a_{i}\right)^{\prime}}{f(\cdot)(1-r)(V-v)}
$$

From (19), we can have partial derivatives below:

$$
\left\{\begin{array}{l}
\frac{\partial\left(x^{*}+x_{0}\right)}{\partial a_{i}}-\frac{\partial\left(y^{*}+y_{0}\right)}{\partial a_{i}}=\frac{h\left(c o n \_m m\right)-g\left(c o n \_s m\right)}{h\left(c o n \_m m\right)+g\left(c o n \_s m\right)} \times \frac{C\left(a_{i}\right)^{\prime \prime}}{f(\cdot)(1-r)(V-v)}>0 \\
\frac{\partial\left(x^{*}+x_{0}\right)}{\partial c o n \_m m}-\frac{\partial\left(y^{*}+y_{0}\right)}{\partial c o n \_m m}=\frac{C\left(a_{i}\right)^{\prime}}{f(\cdot)(1-r)(V-v)} \cdot \frac{2 h\left(c o n \_m m\right)^{\prime} g\left(c o n \_s m\right)}{\left[h\left(c o n \_m m\right)+g\left(c o n \_s m\right)\right]^{2}}>0 \\
\frac{\partial\left(\frac{\partial\left(x^{*}+x_{0}\right)}{\partial a_{i}}-\frac{\partial\left(y^{*}+y_{0}\right)}{\partial a_{i}}\right)}{\partial c o n \_m m}=\frac{C\left(a_{i}\right)^{\prime \prime}}{f(\cdot)(1-r)(V-v)} \cdot \frac{2 h\left(c o n \_m m\right)^{\prime} g\left(c o n \_s m\right)}{\left[h\left(c o n \_m m\right)+g\left(c o n \_s m\right)\right]^{2}}>0 \\
\frac{\partial\left(x^{*}+x_{0}\right)}{\partial c o n \_s m}-\frac{\partial\left(y^{*}+y_{0}\right)}{\partial c o n \_s m}=\frac{C\left(a_{i}\right)^{\prime}}{f(\cdot)(1-r)(V-v)} \cdot \frac{-2 h\left(c o n \_m m\right) g\left(c o n \_s m\right)^{\prime}}{\left[h\left(c o n \_m m\right)+g\left(c o n \_s m\right)\right]^{2}}<0 \\
\frac{\partial\left(\frac{\partial\left(x^{*}+x_{0}\right)}{\partial a_{i}}-\frac{\partial\left(y^{*}+y_{0}\right)}{\partial a_{i}}\right)}{\partial c o n \_s m}=\frac{C\left(a_{i}\right)^{\prime \prime}}{f(\cdot)(1-r)(V-v)} \cdot \frac{-2 h\left(c o n \_m m\right) g\left(c o n \_s m\right)^{\prime}}{\left[h\left(c o n \_m m\right)+g\left(c o n \_s m\right)\right]^{2}}<0
\end{array}\right.
$$

Proposition 4: Because the manufacturing industry is more stimulating to the local economy than the productive service industry, therefore local government officials have a natural inclination to prefer manufacturing industry more than productive service industry, namely more inclined to pull up the level of manufacturing agglomeration. The higher the connection between various industries within local manufacturing industry, the greater the gap between the two industries' pulling effect on the local economy, the stronger this tendency. On the other hand, the higher the connection between the local productive service industry and the manufacturing industry, the smaller the gap between the two industries' pulling effect on the local economy, the weaker this tendency is.

\section{Empirical Evidence}

\subsection{Econometric Model Setting}

Based on the theoretical model in section 2, this section uses econometric models to try to provide some proof. Econometric models are set as below:

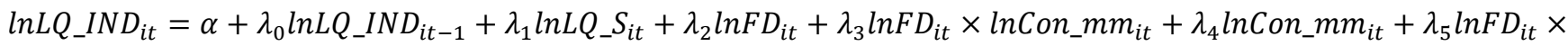

$$
\begin{aligned}
& \text { lnCon_sm } i t+\lambda_{6} \text { lnCon_sm }_{i t}+\sum \gamma_{1} X_{1, i t}+\mu_{1, i}+\varepsilon_{1, i t}
\end{aligned}
$$

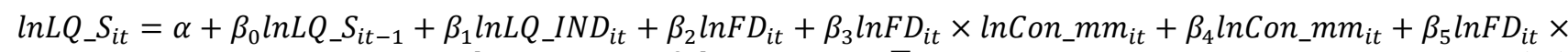

$$
\begin{aligned}
& \text { lnCon_sm } i t+\beta_{6} \text { lnCon_sm }_{i t}+\sum \gamma_{2} X_{2, i t}+\mu_{2, i}+\varepsilon_{2, i t}
\end{aligned}
$$

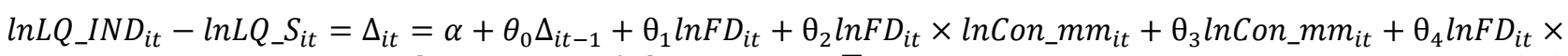

$$
\begin{aligned}
& \text { lnCon_sm } i t+\theta_{5} \text { lnCon_sm }_{i t}+\sum \gamma_{3} X_{3, i t}+\mu_{3, i}+\varepsilon_{3, i t}
\end{aligned}
$$

In (21), (22), (23), i represents region, $t$ represents time, $\mu_{1, i}$ 、 $\mu_{2, i}$ and $\mu_{3, i}$ are fixed effects. In this section, we choose 282 prefectural cities in China as samples, sample window spans from 2003 to 2015, which means the sample are panel data. All the data are collected from "CHINA CITY STATISTICAL YEARBOOK", "CHINA STATISTICAL YEARBOOK" and every provincial statistical yearbook. The variables are described as below:

$L Q_{-} I N D_{i t}, L Q_{-} S_{i t}$ and $\Delta_{i t}: L Q_{-} I N D_{i t}$ is location entropy of urban manufacturing industry, which is measured by "(Employment number of prefectural manufacturing industry / Employment number of manufacturing industry in the whole nation) / (Prefectural total employment number / total employment number in the whole nation)". $L Q_{-} S_{i t}$ is the location entropy of urban productive service industry, which is measured by "(Employment number of prefectural productive service industry / Employment number of productive service industry in the whole nation) / (Prefectural total employment number / total employment number in the whole nation)". $\Delta_{i t}=\ln L Q_{-} I N D_{i t}-\ln L Q_{-} S_{i t}$. Because the statistics published by China does not contain the prefectural output value of manufacturing and productive service industry, we instead use the number of workers of manufacturing and productive services industry in each city to calculate the location entropy of urban manufacturing and productive service industry based on the statistics published by "CHINA CITY STATISTICAL YEARBOOK". About the definition of productive service industry, we take the practice of $\mathrm{Gu}$ (2010) [26] and Liu et al. (2017) [27] as reference, use "Transportation and storage postal service", "Information transmission, computer services, and software industry", "Finance", "Leasing and business services" and "Scientific research, technical service and geological exploration industry" to represent productive service industry. The introduction of first lag of dependent variable in (21), (22) and (23) is based on the practice of Zhu et al. (2012) [28], who use the first lag of dependent variable to represent the cumulative cycle effect in the process of industrial agglomeration.

$F D_{i t}$ : The degree of efforts of local government officials. We use the degree of fiscal decentralization of local government as proxy for the degree of efforts of local government officials, because fiscal decentralization constitutes an important source of incentive for local government officials (Zhou, 2007) [23]. Under fiscal decentralization, the fiscal revenue and expenditure is closely related to the local economy, under the current political system 
and the system of official promotion, local officials will spare no effort to pull local economy performance to compete with other local governments (Yu and Liu, 2018) [24]. We take the practice of Guo and Jia (2010) [29] as reference, define the fiscal expenditure decentralization as:

$F D_{-} e x d_{i t}=$ Fiscal expenditure per capita on the level of prefectural city/( Fiscal expenditure per capita on the level of prefectural city + Fiscal expenditure per capita on the level of provincial level + Fiscal expenditure per capita on the level of central government)

Fiscal revenue decentralization $\left(F D \_r e_{i t}\right)$ can be defined similarly.

Con_sm ${ }_{i t}$ : The connection between manufacturing industry and productive services industry. The best data source for measuring the connection between different industries is the economic input-output table. Because the lowest level of input-output table published by China is provincial level, and only contains data of 2002, 2007 and 2012 (Data source: "CHINA REGIONAL INPUT-OUTPUT TABLE"), we first calculate each province's connection between manufacturing industry and productive services industry in 2002, 2007, 2012 based on these provincial input-output table. The calculation formula is:

Provincial connection between manufacturing industry and productive services industry $\left(\right.$ Con_sm $\left._{i t}\right)=$ (Production service industry's intermediate output to the manufacturing industry + Manufacturing industry's intermediate output to the productive service industry) / Provincial GDP

Then, in line with the data period of the sample we take, based on the nearest neighbour principle, we fill the connection between manufacturing industry and productive services industry of 2003, 2004 with the value of 2002, fill the connection of 2005, $2006,2008,2009$ with the value of 2007, fill the connection of 2010, 2011, 2013, 2014, 2015 with the value of 2012. At last, we take the value of connection on the provincial level as every prefectural cities' connection in that province.

Con_mm $m_{i t}$ : Connection between different industries within the manufacturing industry. Similar with Con_sm $_{i t}$, we use the formula below to calculate the connection between different industries within the manufacturing industry:

Connection between different industries within the manufacturing industry $\left(C o n \_m m_{i t}\right)=$ Total input and output of each industry within the manufacturing industry / Provincial GDP

Data other than 2002, 2007 and 2012 is filled in the same way as Con_smit.

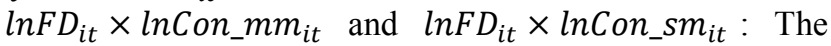
interact between fiscal decentralization variable and industrial connection variable. The introduction of interacts is to identify the sign of the two order mixed partial derivative in (17), (18) and (20).

$X_{1, i t}$ : Control variables affecting the agglomeration of prefectural manufacturing industry. According to the existing researches, control variables include the market scale $\left(D e_{i t}\right)$ pointed out by the theory of "externality of currency" in new economic geography, we measure it with prefectural total retail sales of consumer goods. The level of prefectural economic development (GDP_per ${ }_{i t}$ ), we measure it with prefectural GDP per capita. Foreign direct investment $\left(F D I_{i t}\right)$, we measure it with prefectural foreign direct investment divided by prefectural GDP. Pollution $\left(\right.$ Water $\left._{i t}\right)$, we measure it with prefectural sewage discharge per capita. Level of infrastructure construction ( $\left(n f r a_{i t}\right)$, we measure it with road area per capita in municipal district, which is often used in existing literature to proxy transportation cost and transaction cost. Wage level $\left(W_{a g e}\right)$, we measure it with prefectural average wage. Tax burden level $\left(\operatorname{Tax}_{i t}\right)$, we measure it with prefectural fiscal revenue divided by prefectural GDP. Level of government expenditure $\left(P u b_{i t}\right)$, we measure it with prefectural fiscal expenditure divided by prefectural GDP. Scale of loan $\left(\right.$ Find $\left._{i t}\right)$, we measure it with loan balance of financial institutions divided by prefectural GDP.

$X_{2, i t}$ : Control variables affecting the agglomeration of prefectural productive service industry. According to the existing researches, control variables includes Level of infrastructure construction ( $\left.I n f r a_{i t}\right)$, foreign direct investment $\left(F D I_{i t}\right)$, level of prefectural economic development (GDP_per $i t)$, tax burden level $\left(\right.$ Tax $\left._{i t}\right)$, level of government expenditure $\left(P u b_{i t}\right)$. For productive service industry, prefectural knowledge stock and level of information construction are considered to be crucial for their location decision (Chen et al., 2009) [15], therefore we also take prefectural knowledge stock $\left(K_{n o w}\right)$, which is measured by prefectural number of full-time teachers in colleges and universities per capita, and level of information construction $\left(\right.$ Inform $\left._{i t}\right)$, which is measured by prefectural mobile phone number per capita, as control variables.

$X_{3, i t}$ : Control variables that might affect $\Delta_{i t}$, which includes tax burden level ( $\left.\operatorname{Tax}_{i t}\right)$, level of government expenditure $\left(P u b_{i t}\right)$, level of infrastructure construction $\left(\right.$ Infra $\left._{i t}\right)$, market scale $\left(D e_{i t}\right)$, foreign direct investment $\left(F D I_{i t}\right)$, level of prefectural economic development $\left(G D P_{-}\right.$per $\left._{i t}\right)$, wage level $\left(\right.$ Wage $\left._{i t}\right)$, pollution $\left(\right.$ Water $\left._{i t}\right)$, prefectural knowledge stock $\left(K_{n o w}\right)$ and level of information construction (Inform it $_{\text {) }}$.

\subsection{Estimation Method and Empirical Results}

The particularity of industrial agglomeration is that, it often has a symbiotic relationship with other economic and social development variables, which will result in a reverse causality in a linear econometric model. Dynamic panel data model has the advantage of flexible selection of instrument variables, therefore it is an effective solution to solve the possible reverse causality between industrial agglomeration and different independent variables. In (21), we choose $L Q_{-} S_{i t}, F D_{i t}, C o n_{-} s m_{i t}$, Con_mm $m_{i t}$, Tax $i t$ and Water ${ }_{i t}$ to be endogenous variables. In (22), we choose $L Q_{-} I N D_{i t}, F D_{i t}$, Con_sm ${ }_{i t}, C o n \_m m_{i t}, \operatorname{Tax}_{i t}$ to be endogenous variables. In (23), we choose $F D_{i t}, C_{-}$Com $_{i t}, C_{0}$ mm $_{i t}$, Tax $_{i t}$, Water $_{i t}$ to be endogenous variables. We take these endogenous variables' two and above lags as instruments (Roodman, 2009) [30] in order to deal with possible endogeneity problem of these variables. We use twostep, robust, system GMM method to do the estimation. Results are listed in table $1-$ table 3. 
Table 1. Estimation results of (21): Industrial Agglomeration.

\begin{tabular}{|c|c|c|c|c|}
\hline Model & (1) & (2) & (3) & (4) \\
\hline Decentralization index & $F D_{-} e x d_{i t}$ & $F D_{-} e x d_{i t}$ & $F D \_r e_{i t}$ & $F D \_r e_{i t}$ \\
\hline \multirow[t]{2}{*}{ L. $L Q_{-} I N D_{i t}$} & $0.8706^{* * *}$ & $0.8983^{* * *}$ & $0.8843^{* * *}$ & $0.8917^{* * * *}$ \\
\hline & (35.5990) & (30.0261) & (35.2783) & (30.4169) \\
\hline \multirow[t]{2}{*}{$F D_{i t}$} & $-0.5727 * *$ & $0.8004 * * *$ & $-0.3721 * * *$ & $0.2117 * *$ \\
\hline & $(-2.5514)$ & $(4.1818)$ & $(-3.5013)$ & $(2.3461)$ \\
\hline \multirow[t]{2}{*}{$F D_{i t} \times P u b_{i t}$} & 0.0510 & $0.2237 * * *$ & -0.0244 & 0.0155 \\
\hline & $(1.2172)$ & $(3.9883)$ & $(-1.0697)$ & $(0.5880)$ \\
\hline \multirow[t]{2}{*}{ Conn_mm $m_{i t}$} & $0.0955 * *$ & & 0.0552 & \\
\hline & $(2.5172)$ & & $(1.0688)$ & \\
\hline \multirow[t]{2}{*}{ Conn_sm $m_{i t}$} & $-0.2353 * * *$ & & $-0.2137 * * *$ & \\
\hline & $(-3.1281)$ & & $(-3.0876)$ & \\
\hline \multirow[t]{2}{*}{$F D_{i t} \times C o n n \_m m_{i t}$} & $0.1259 * *$ & & 0.0243 & \\
\hline & $(2.1864)$ & & $(0.6631)$ & \\
\hline \multirow[t]{2}{*}{$F D_{i t} \times$ Conn $_{-}$sm $_{i t}$} & $-0.3694 * * *$ & & $-0.1746^{* * *}$ & \\
\hline & $(-3.5086)$ & & $(-3.5434)$ & \\
\hline \multirow[t]{2}{*}{ Conn $_{i t}$} & & -0.0141 & & $0.0388^{*}$ \\
\hline & & $(-0.5067)$ & & $(1.6507)$ \\
\hline Observations & 3384 & 3384 & 3384 & 3384 \\
\hline Control variables & Yes & Yes & Yes & Yes \\
\hline $\operatorname{ar}(1)$ & 0.000 & 0.000 & 0.000 & 0.000 \\
\hline $\operatorname{ar}(2)$ & 0.594 & 0.479 & 0.601 & 0.432 \\
\hline hansen p-value & 0.110 & 0.114 & 0.127 & 0.133 \\
\hline
\end{tabular}

Note: $\mathrm{z}$-statistics or t-statistics in parentheses, ${ }^{* * *} \mathrm{p}<0.01,{ }^{* *} \mathrm{p}<0.05,{ }^{*} \mathrm{p}<0.1$. All variables have been transfered to logarithm. It is welcome to ask the author for complete estimation results.

From model (1) and model (3) in table 1, we can see that the coefficients of Con_mm $m$ and its interact with $F D_{i t}$ are significantly positive. Meanwhile, the coefficients of Con_sm it $_{\text {it }}$ and its interact with $F D_{i t}$ are significantly negative. Model (2) and model (4) in table 1 are used to identify the total marginal effect of $F D_{i t}$ on the dependent variable, in which Conn $_{i t}$ is the overall measurement of information contained in Con_mmit and Con_sm ${ }_{i t}$. Conn $n_{i t}$ is calculated by formula below:
Conn $_{i t}=($ Production service industry's intermediate output to the manufacturing industry + Manufacturing industry's intermediate output to the productive service industry + Total input and output of each industry within the manufacturing industry) / Provincial GDP

From model (2) and model (4) in table 1, we can see that the coefficients of $F D_{i t}$ are significantly positive. The results in table 1 above verify (17).

Table 2. Estimation results of (22): Productive service industry Agglomeration.

\begin{tabular}{|c|c|c|c|c|}
\hline Model & (1) & (2) & (3) & (4) \\
\hline Decentralization index & $F D \_e x d_{i t}$ & $F D_{-}$exd ${ }_{i t}$ & $F D \_r e_{i t}$ & $F D \_r e_{i t}$ \\
\hline$L . L Q \_S_{i t}$ & $\begin{array}{l}0.7671 \text { *** } \\
(22.5224)\end{array}$ & $\begin{array}{l}0.8073^{* * *} \\
(26.5226)\end{array}$ & $\begin{array}{l}0.7581 * * * \\
(22.2152)\end{array}$ & $\begin{array}{l}0.7939 * * * \\
(25.4528)\end{array}$ \\
\hline$F D_{i t}$ & $\begin{array}{l}0.6974 * * * \\
(3.5951)\end{array}$ & $\begin{array}{l}0.1395^{* *} \\
(2.0630)\end{array}$ & $\begin{array}{l}0.4367 * * * \\
(3.4302)\end{array}$ & $\begin{array}{l}0.0985^{* * *} \\
(2.8253)\end{array}$ \\
\hline Conn_mm $m_{i t}$ & $\begin{array}{l}-0.1098 * * * \\
(-2.9491)\end{array}$ & & $\begin{array}{l}-0.1075^{* *} \\
(-2.3221)\end{array}$ & \\
\hline Conn_sm $m_{i t}$ & $\begin{array}{l}0.2637 * * * \\
(4.8106)\end{array}$ & & $\begin{array}{l}0.3273 * * * \\
(4.1149)\end{array}$ & \\
\hline$F D_{i t} \times C o n n \_m m_{i t}$ & $\begin{array}{l}-0.1529 * * * \\
(-2.7062)\end{array}$ & & $\begin{array}{l}-0.0780^{* *} \\
(-2.4681)\end{array}$ & \\
\hline$F D_{i t} \times C_{C o n n} s_{-} m_{i t}$ & $\begin{array}{l}0.3938^{* * *} \\
(4.4345)\end{array}$ & & $\begin{array}{l}0.2284 * * * \\
(3.8092)\end{array}$ & \\
\hline Conn $_{i t}$ & & $\begin{array}{l}0.0992 * * * \\
(2.8562)\end{array}$ & & $\begin{array}{l}0.1799 * * * \\
(4.1066)\end{array}$ \\
\hline$F D_{i t} \times$ Conn $_{i t}$ & & $\begin{array}{l}0.1679 * * * \\
(3.0143)\end{array}$ & & $\begin{array}{l}0.1102 * * * \\
(4.0321)\end{array}$ \\
\hline Observations & 3384 & 3384 & 3384 & 3384 \\
\hline Control variables & Yes & Yes & Yes & Yes \\
\hline $\operatorname{ar}(1)$ & 0.000 & 0.000 & 0.000 & 0.000 \\
\hline $\operatorname{ar}(2)$ & 0.809 & 0.898 & 0.780 & 0.930 \\
\hline hansen p-value & 0.119 & 0.112 & 0.146 & 0.121 \\
\hline
\end{tabular}

Note: $\mathrm{z}$-statistics or t-statistics in parentheses, ${ }^{* * *} \mathrm{p}<0.01, * * \mathrm{p}<0.05, * \mathrm{p}<0.1$. All variables have been transfered to logarithm. It is welcome to ask the author for complete estimation results. 
From model (1) and model (3) in table 2, we can see that Con_mmit and its interact with $F D_{i t}$ are significantly negative. Con_smit and its interact with $F D_{i t}$ are significantly positive. Model (2) and model (4) in table 2 are used to identify the total marginal effect of $F D_{i t}$ on the dependent variable, in which Conn $_{i t}$ is calculated in the same way as table 1 . From model (2) and model (4) in table 2, we can see that the coefficients of $F D_{i t}$ are significantly positive. The results in table 2 above verify (18).

Table 3. Estimation results of (23).

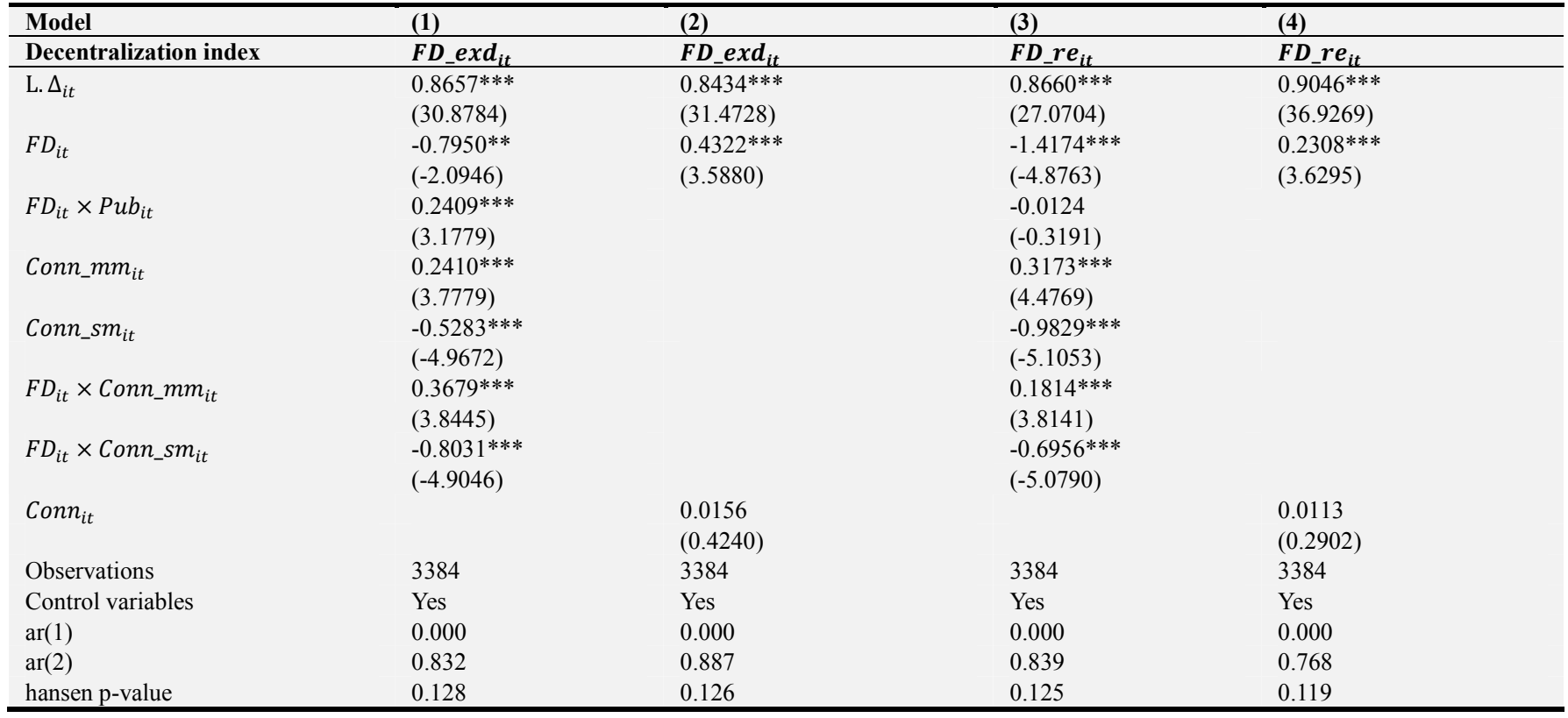

Note: $\mathrm{z}$-statistics or t-statistics in parentheses, ${ }^{* * *} \mathrm{p}<0.01, * * \mathrm{p}<0.05, * \mathrm{p}<0.1$. All variables have been transfered to logarithm. It is welcome to ask the author for complete estimation results.

From model (1) and model (3) in table 3, we can see that Con_mmit and its interact with $F D_{i t}$ are significantly positive. Con_sm it and its interact with $F D_{i t}$ are significantly negative. Model (2) and model (4) in table 3 are used to identify the total marginal effect of $F D_{i t}$ on the dependent variable, in which Conn $_{i t}$ is calculated in the same way as table 1 . From model (2) and model (4) in table 4, we can see that the coefficients of $F D_{i t}$ are significantly positive. The results in table 3 above verify (20).

Until now, (17), (18) and (20) has all been verified, therefore proposition 1 - proposition 4 all pass empirical test.

\section{Conclusions and Discussions}

\subsection{Conclusions}

Based on the Chinese style promotion game, we take the degree of fiscal decentralization as the proxy variable for the efforts of local government officials, and provide an analysis of how government officials' behavior and preference affect the evolutionary trajectory of local manufacturing industry agglomeration and productive service industry agglomeration through connections between different industries when government officials are trying to maximize their probability of promotion, which provides a new perspective for the explanation of the causes of industrial agglomeration in China. We come up with the following conclusions.

(1) In the Chinese promotion game, local government officials will promote the agglomeration of local manufacturing industry and the agglomeration of productive services in order to maximize the probability of their promotion.

(2) Due to the producer services industry' natural dependence on the manufacturing industry, the higher the connection between local producer services industry and manufacturing industry, the stronger the pulling effect of producer services industry on local economy, therefore local government officials will be more willing to pull up the level of local productive service industry agglomeration and reduce the level of manufacturing industry agglomeration relatively. On the other hand, the higher the connection among different industries within manufacturing industry, the stronger the pulling effect of manufacturing industry on local economy, therefore local government officials will be more willing to pull up the level of local manufacturing industry agglomeration and reduce the level of productive service industry agglomeration relatively.

(3) Because the manufacturing industry is more stimulating to the local economy than the productive service industry, therefore local government officials have a natural inclination to prefer manufacturing industry more than productive service industry, namely more inclined to pull up the level of manufacturing agglomeration. The higher the connection between various industries within local manufacturing industry, the greater the gap between the two industries' 
pulling effect on the local economy, the stronger this tendency. On the other hand, the higher the connection between the local productive service industry and the manufacturing industry, the smaller the gap between the two industries' pulling effect on the local economy, the weaker this tendency is.

The conclusions above reveal that, under the promotion game between local governments, the different situations of industrial connections local governments confront have a significant influence on local governments' indusry selection preference. The possible policy implication of the conclusions above for China might be: In the current process of developing the productive service industry in China, provincial governments should play fully role of guidance and supervision when prefectural governments under their jurisdictions make local industrial policies, by helping prefectural governments to make local industrial policy scientifically and optimize local industrial structure. Prefectural governments should give more priority and focus on the development of productive service industry whose connection with local manufacturing industry is higher, and promote the production service industry to be more closely embedded into the value chain of local manufacturing industry, in order to make the potential energy of local governments' mutual competition better transfer into the kinetic energy of development of local productive service industry agglomeration.

\subsection{Discussions}

This study is mainly based on the research paradigm of promotion game and the paradigm of neoclassical economics. The influence of "competition interaction" between local governments on the agglomeration and evolution of manufacturing and productive service industry is examined. However, the interaction between local governments is not just competing with each other. As the social and economic division of labor becomes more and more refined, in the case of low transaction and transport costs, there should be "cooperative interaction" between adjacent local governments. For example, in the city cluster, some cities specialize in the agglomeration of productive services in their jurisdictions to provide services to its surrounding cities, while some local governments specialize in manufacturing agglomeration in their jurisdictions to make full use of their comparative advantages. Such "cooperation and interaction" might lead to a change in the objective function of the local government's optimization problem. The empirical evidence provided in this article is based on all the prefectural samples in China, yet it cannot be excluded that in areas where transportation infrastructure is developed and transaction cost is relatively low in China, such as the Yangtze River Delta city group, the Pearl River Delta city group and the Jiangsu and Zhejiang coastal area, the objective function of local governments' optimization problem is likely to be alienated. Therefore, it may be the direction of future researches to discuss how to bring the transport transaction costs between adjacent areas into the objective function of local governments' optimization problem.

\section{References}

[1] Ohlin, B. International and Interregional Trade [J]. Harvard Economic Studies, Cambridge, MA, 1933.

[2] Christaller, W. Central Places in Southern Germany [M]: Prentice-Hall; 1966.

[3] Henderson, J. V. Urban Development: Theory, Fact, and Illusion [J]. OUP Catalogue, 1991.

[4] Krugman, P. R. Geography and Trade [M]: MIT press; 1991.

[5] Wilson, J. D. Theories of Tax Competition [J]. National tax journal, 1999, 269-304.

[6] Brakman, S., Garretsen, H., Van Marrewijk, C. Locational Competition and Agglomeration: The Role of Government Spending [J], 2002.

[7] Bucovetsky, S. Public Input Competition [J]. Journal of Public Economics, 2005, 89(9): 1763-87.

[8] Egger, H., Falkinger, J. The Role of Public Infrastructure and Subsidies for Firm Location and International Outsourcing [J]. European Economic Review, 2006, 50(8): 1993-2015.

[9] Commendatore, P., Kubin, I., Petraglia, C. Productive Public Expenditure in a New Economic Geography Model [J]. Économie Internationale, 2008,(2):133-59.

[10] Fenge, R., von Ehrlich, M., Wrede, M. Public Input Competition and Agglomeration [J]. Regional Science and Urban Economics, 2009, 39(5): 621-31.

[11] Tsai, J.-F. Agglomeration and Local Public Goods with Spillovers [J]. Academia Economic Papers, 2017, 45(1): 129.

[12] JIN, Y., CHEN, Z., LV, M. Industry Agglomeration in China: Economic Geography, New Economic Geography and Policy [J]. Economic Research Journal, 2006, (04): 79-89.

[13] HUANG, J. L., LI, K. W. Foreign Trade, Local Protectionism and Industrial Location in China [J]. China Economic Quarterly, 2006,(02):733-60.

[14] LIANG, Q., WU, J. Fiscal Transfers and Industrial Agglomeration [J]. China Economic Quarterly, 2008, (04): 1247-70.

[15] CHEN, J. J., CHEN, G. L., HUANG, J. Research on the Agglomeration of Productive Service Industry and Its Influencing Factors from the Perspective of New Economic Geography--Empirical Evidence from 222 Cities in China [J]. Management World, 2009, (04): 83-95.

[16] HE, C. F., ZHU, Y. G., ZHU, S. J. Industrial Attributes, Provincial Characteristics and Industrial Agglomeration in China [J]. Acta Geographica Sinica, 2010, (10): 1218-28.

[17] HU, C. G., CHENG, H. F., YU, B."Active Government" and the Evolution of Agglomeration Economic Circle --an Analytical Framework Based on the Agglomeration Economic Circle of the Yangtze River Delta [J]. Management World, 2011, (02): 61-9+80.

[18] ZONG, J. F., ZHU, J. J. Dose Productive Public Input Change the Distribution of Industrial Agglomeration Based on New Economic Geography? [J]. Shanghai Journal of Economics, 2013, (02): 3-12. 
[19] LI, S. J., HUAN, M. L., WEI, K. L. Does Public Policy Affect Regional Industrial Agglomeration in China? An Empirical Analysis Based on Provincial Data [J]. Scientific Decision Making, 2017, (02): 1-25.

[20] LI, S. J., HU, G. L., GAO, J. The Evolution of China's Industrial Agglomeration During the Transition Period: Theoretical Review, Research Progress and Exploratory Thinking [J]. Management World, 2014, (04): 165-70.

[21] LIN, Y. F. Development and Transformation: Trends, Strategies and Spontaneity Ability [J]. Journal of Beijing Jiaotong University(Social Sciences Edition), 2008, (04): 1-3.

[22] ZHOU, L. A. The Incentive and Cooperation of Government Officials in the Political Tournaments: An Interpretation of the Prolonged Local Protectionism and Duplicative Investments in China [J]. Economic Research Journal, 2004, (06): 33-40.

[23] ZHOU, L. A. Governing China' S Local Officials: An Analysis of Promotion Tournament Model [J]. Economic Research Journal, 2007, (07): 36-50.

[24] YU, Y. Z., LIU, D. Y."Chinese Financial Decentralization" and Total Factor Productivity: "Competition" or "Competitive Advantage" [J]. Finance \& Trade Economics, 2018, (1): 23-37.
[25] Boyd, Vandenberghe, Faybusovich. Convex Optimization [J]. IEEE Transactions on Automatic Control, 2006, 51(11): 1859-.

[26] GU, N. H. Effects and Channels between Producer Services and Profits of Industries -- Empirical Research Based on Cities' Panel Data and Sfa Model [J]. China Industrial Economics, 2010, (05): 48-58.

[27] LIU, Y., XIA, J. C., LI, Y. Producer Services Agglomeration and Manufacturing Upgrading [J]. China Industrial Economics, 2017, (07): 24-42.

[28] ZHU, Y. M., YANG, L. S., LV, H. J., SHEN, X. Research on the Shortage of Resources, Environmental Damage and the Effect of Industrial Agglomeration--an Empirical Analysis of China's Provincial Industrial Agglomeration in Twenty-One Century [J]. Management World, 2012, (11): 28-44.

[29] GUO, Q. W., JIA, J. X. Fiscal Decentralization, Government Structure and Local Government's Expenditure Size [J]. Economic Research Journal, 2010, (11): 59-72+87.

[30] Roodman, D. How to Do Xtabond2: An Introduction to Difference and System Gmm in Stata [J]. Stata Journal 2009, 9(1): 86-136. 